\title{
The advisability of high-rise construction in the city
}

\author{
Natalia Sergievskaya ${ }^{1 *}$, Tatyana Pokrovskaya $^{2}$ and Natalya Vorontsova $^{3}$ \\ ${ }^{1}$ Moscow State University of Civil Engineering, Yaroslavskoe shosse, 26, Moscow,129337, Russia \\ ${ }^{2}$ Moscow Polytechnic University, Bolshaya Semenovskaya str., 38, Moscow, 107023, Russia \\ ${ }^{3}$ Vyatka State University, Moskovskaya str., 36, Kirov, 610000, Russia
}

\begin{abstract}
In this article there discusses the question of advisability highrise construction, the reasons for its use, both positive and negative sides of it. On the one hand, a number of authors believe that it is difficult to avoid high-rise construction due to the limited areas in very large cities. On the other hand, a number of other authors draw attention to the problems associated with high-rise construction. The author of the article analyses examples of high-rise construction in several countries (UAE, Dubai "Burj Khalifa"; Japan "Tokyo Sky Tree"; United States of America, "Willis Tower"; Russia "Federation Tower") and proves the advisability of high-rise construction in the city.
\end{abstract}

\section{Introduction}

Nowadays high-rise construction is becoming more and more actual in the world. This is due to the fact the urbanization urban space is increasing and there is also accelerated development of construction technologies and technology of engineering support of buildings. As it was considered in USSR and then in Russia, high-rise buildings have height of $75 \mathrm{~m}$ that is more 25 floors. As for other countries, high-rise buildings have height from 35 to 100 metres. In the US and Europe under the skyscraper there is understood building above $150 \mathrm{~m}$, and in other countries it is higher than $100 \mathrm{~m}$. In Russia, the skyscrapers are considered buildings of height $75 \mathrm{~m}$ or more [1]. High-rise buildings play an important role in technical progress. They also promote economic development. In the modern world highrise construction occupies leading positions in the construction industry. Skyscrapers are becoming commonplace in big cities. Thanks to high-rise construction, developing countries show their opportunities. There are following factors:

1. Economic factors. High-rise construction develops very quickly in prestigious areas in large cities thanks to the high cost of land in megapolices, etc

2. Commercial interest. It is more profitable to implement large investment projects on high-rise construction.

3. Political image. High-rise and original buildings show economic stability and prestige of countries.

\footnotetext{
*Corresponding author:doptaganka@yandex.ru
} 
Nowadays economic factors play the most important role [2]. An international experience has shown, the buildings which height is 30 to 50 floors are most beneficial from an economic point of view. In this regard, high-rise construction is the most important direction in the modern big city. High-rise buildings may have different purposes. They may be hotels, offices, apartment houses. Usually high-rise buildings are multifunctional, that is there are parking garages, shops, offices, cinemas etc. As mentioned above high-rise construction came due to a significant shortage of territory for construction in megapolises. There is also a lack of land for office and hotel space in big cities.

The first international Symposium of the Council on tall buildings and urban environment was in 1971. The Council on Tall buildings and Urban Habitat developed and adopted international classification of skyscrapers depending on their height. The Council specifies the following types of skyscrapers (tall buildings).

1. Skyscrapers are buildings from 100 to $300 \mathrm{~m}$.

2. High-rise buildings are buildings from 300 to $600 \mathrm{~m}$.

3. Mega high building are buildings with the height more than $600 \mathrm{~m}$.

At present time the volume of construction of skyscrapers significantly increased. Highrise construction is actively developing in the congested cities of Asia. There is trying to solve housing problem with the help the construction of high-rise buildings. Last 10 years there exist the construction of high-rise buildings which are multifunctional [3].

\section{Review}

Let us consider the tallest buildings in the world, in the countries; the most green buildings etc. High-rise buildings appeared in the United States. The term "skyscraper" appeared thanks to offices with a height of over 10 floors. These offices as well as the term "skyscraper" appeared in Chicago in 1891. In the following decades, the construction of skyscrapers actively took place in big cities in USA.

High-rise construction began in Europe in the late 1950 - early 1960. At first after the Second World War there was the restoration of the ruined historical centers of cities. There was also implemented mass economical housing construction of houses of the average number of storeys. After it, there began to construct high-rise buildings. As for Russia, highrise construction began in 1913. At that time the seven-story building was built. Nowadays Russia has 38 skyscrapers and it ranks 15 th in the global rankings. If we look at international experience with respect to Moscow, that it is better to master 2-3 of the construction site on small plots on the outskirts of the capital. These complexes can have both social (e.g., new jobs at the place of residence) and compositional value. If you place them on the outskirts, it will allow not to disturb the panorama of the historic part of the city $[4,5]$.

The rating of the International Council on tall buildings and urban habitat (ctbuh) is one of the important rankings, which is published every year. It gives the description of the 100 tallest buildings in the world. In accordance with it (the classification of CTBUH), today there are more than 3.8 thousand skyscrapers in the world. Their height is $150 \mathrm{~m}$. There are 115 buildings above $300 \mathrm{~m}$. There are 115 buildings above $300 \mathrm{~m}$. Four Russian skyscrapers entered the hundred tallest buildings. These are "Federation Tower", Mercury City Tower and Eurasia and others.

The largest number of skyscrapers was built in 2017 year. They had 144 and they are above 200 metres. The most of the buildings were built in China (76). The following are USA (10 skyscrapers) and South Korea (7 skyscrapers). In this year, the highest constructed building has become an international financial center in China. It is $599 \mathrm{~m}$ and it has 115 floors. Let us consider tall buildings with the title of "the most". The tallest building, the greenest building etc. 
Table 1. The tallest buildings in the world

\begin{tabular}{|c|c|c|c|c|c|}
\hline $\mathrm{N}$ & The tallest building & Country & $\begin{array}{l}\text { The name of the } \\
\text { high-rise building }\end{array}$ & Height & $\begin{array}{c}\text { The years of } \\
\text { building } \\
\text { creation }\end{array}$ \\
\hline 1 & $\begin{array}{l}\text { the first skyscraper } \\
\text { in the world }\end{array}$ & USA, Chicago & $\begin{array}{c}\text { Insurance } \\
\text { company Home } \\
\text { Insurance } \\
\text { Building }\end{array}$ & $42 \mathrm{~m}$. & $\begin{array}{c}1884- \\
1931 г г .\end{array}$ \\
\hline \multirow[t]{2}{*}{2} & $\begin{array}{l}\text { the tallest building } \\
\text { in the world }\end{array}$ & UAE Dubai & Burj Khalifa & $828 \mathrm{~m}$ & $2004-2010$ \\
\hline & $\begin{array}{l}\text { the tallest building } \\
\text { in Asia }\end{array}$ & $\begin{array}{l}\text { China, } \\
\text { Shanghai }\end{array}$ & Shanghai tower & $632 \mathrm{~m}$ & $2008-2015$ \\
\hline \multirow[t]{2}{*}{10} & $\begin{array}{l}\text { the tallest } \\
\text { residential building }\end{array}$ & $\begin{array}{l}\text { USA, New } \\
\text { York }\end{array}$ & 432 Park Avenue & $\begin{array}{c}425.5 \\
\mathrm{~m}\end{array}$ & $2012-2015$ \\
\hline & $\begin{array}{c}\text { the largest private } \\
\text { home built for one } \\
\text { family }\end{array}$ & $\begin{array}{l}\text { India, } \\
\text { Mumbai }\end{array}$ & & $173 \mathrm{~m}$ & 2010 \\
\hline 11 & $\begin{array}{l}\text { the tallest tower in } \\
\text { the world }\end{array}$ & Japan & Tokyo Sky Tree & $634 \mathrm{~m}$ & $2006-2012$ \\
\hline
\end{tabular}

There consider ten tallest skyscrapers according to "RBK-Nedvizhimost (real estate)". They are shown in Figure 1.

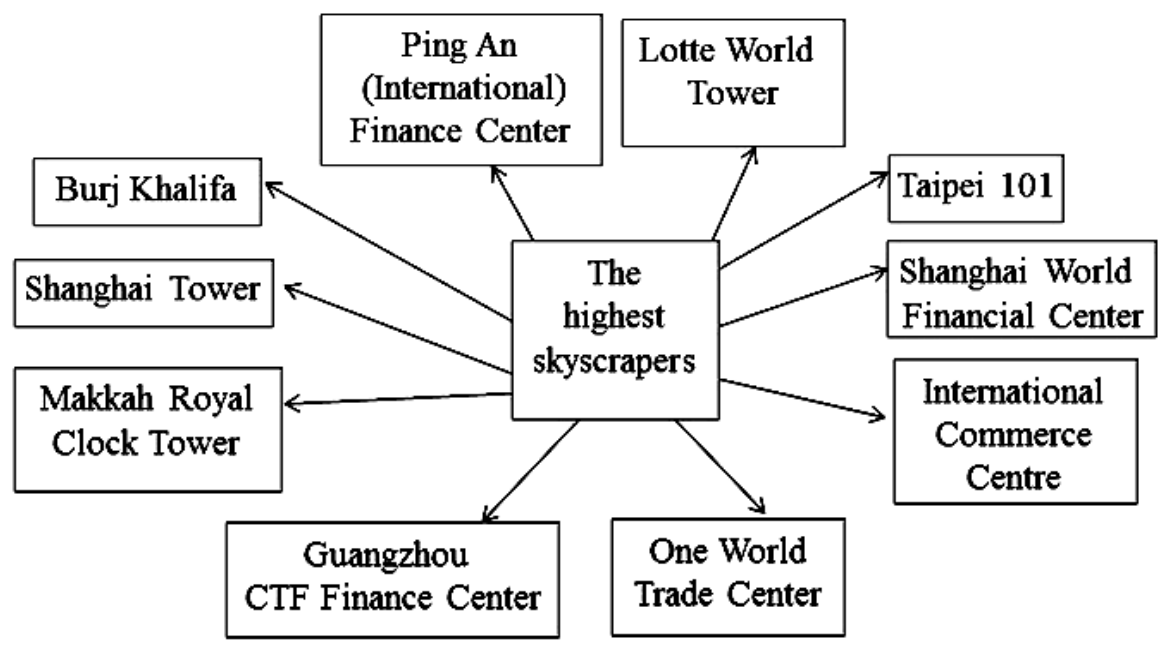

Fig. 1. The tallest skyscrapers according to "RBK-Nedvizhimost (real estate)".

Let us consider the tallest residential buildings. They are shown in Figure 2. 


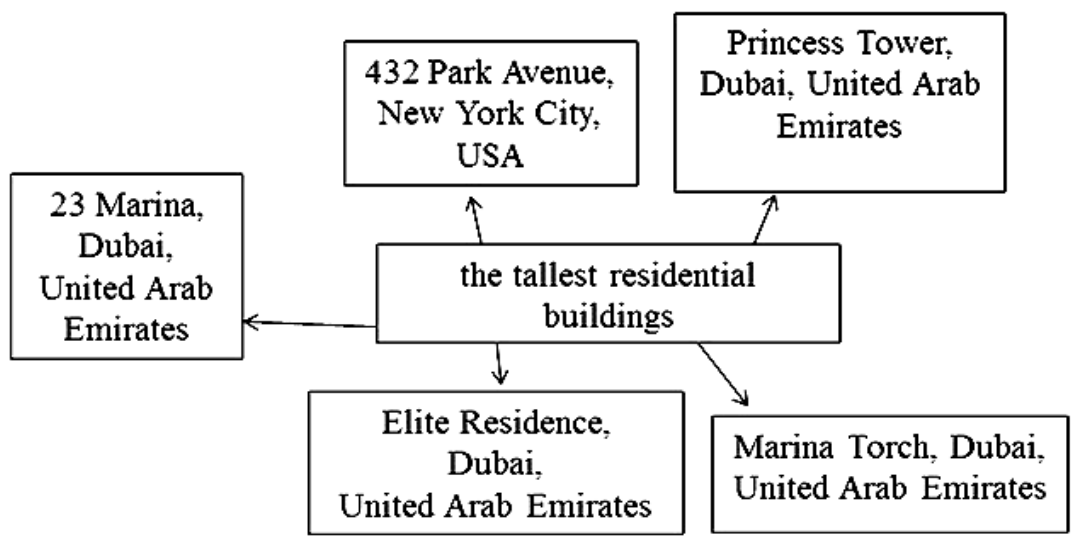

Fig. 2. The tallest residential buildings

Let us consider the tallest towers. They are shown in Figure 3.

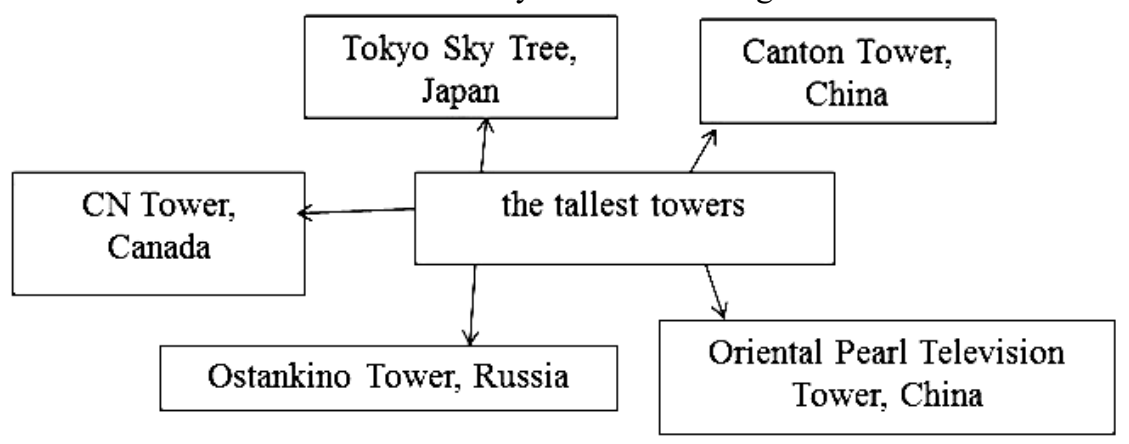

Fig. 3. The tallest towers

Table 2. The highest skyscrapers*

\begin{tabular}{|c|c|c|c|c|c|}
\hline Country & City & $\begin{array}{c}\text { The name of the } \\
\text { skyscraper }\end{array}$ & Height & $\begin{array}{c}\text { number } \\
\text { of floors }\end{array}$ & Appointment \\
\hline UAE & Dubai & Burj Khalifa & $828 \mathrm{~m}$ & 163 & $\begin{array}{c}\text { offices, housing } \\
\text { and hotel }\end{array}$ \\
\hline China & Shanghai & Shanghai Tower & $632 \mathrm{~m}$ & 128 & hotel and offices \\
\hline Saudi Arabia & Makkah & $\begin{array}{c}\text { Makkah Royal Clock } \\
\text { Tower }\end{array}$ & $601 \mathrm{~m}$ & 120 & $\begin{array}{c}\text { multifunctional } \\
\text { complex }\end{array}$ \\
\hline China & $\begin{array}{c}\text { Shenzhe } \\
\mathrm{n}\end{array}$ & $\begin{array}{c}\text { Ping An Finance } \\
\text { Center }\end{array}$ & $599 \mathrm{~m}$ & 115 & offices \\
\hline South Korea & Seoul & $\begin{array}{c}\text { Lotte World Tower } \\
\text { USA }\end{array}$ & $\begin{array}{c}554,5 \\
\mathrm{~m}\end{array}$ & 123 & how \\
\hline York & $\begin{array}{c}\text { One World Trade } \\
\text { Center }\end{array}$ & $\begin{array}{c}541,3 \\
\mathrm{~m}\end{array}$ & 94 & hotel and offices \\
\hline China & $\begin{array}{c}\text { Guangzh } \\
\text { ou }\end{array}$ & $\begin{array}{c}\text { Guangzhou CTF } \\
\text { Finance Center }\end{array}$ & $530 \mathrm{~m}$ & 111 & $\begin{array}{c}\text { multifunctional } \\
\text { complex }\end{array}$ \\
\hline Chiwan & Taipei & $\begin{array}{c}\text { Taipei 101 } \\
\text { offices }\end{array}$ \\
\hline China & Shanghai & $\begin{array}{c}\text { Shanghai World } \\
\text { Financial Center }\end{array}$ & $492 \mathrm{~m}$ & 101 & hotels and offices \\
\hline Kong & $\begin{array}{c}\text { International } \\
\text { Commerce Centre }\end{array}$ & $484 \mathrm{~m}$ & 108 & hotel and offices \\
\hline
\end{tabular}


*Information from "RBC- Nedvizhimost" (real estate).

There consider the most green skyscrapers.

Table 3. The greenest skyscrapers

\begin{tabular}{|c|c|c|c|c|}
\hline $\mathrm{N}$ & Country & City & $\begin{array}{l}\text { The name of } \\
\text { the skyscraper }\end{array}$ & Feature \\
\hline 1 & Bahrain & & $\begin{array}{l}\text { The Bahrain } \\
\text { World Trade } \\
\text { Center Towers }\end{array}$ & $\begin{array}{l}\text { Three very large fans are on the front of the } \\
\text { building. Propellers can produce up to } 1100 \\
\text { MW of electricity per year. }\end{array}$ \\
\hline 2 & China & Guangzhou & $\begin{array}{c}\text { The Pearl } \\
\text { River Tower }\end{array}$ & $\begin{array}{l}\text { Solar batteries, photovoltaic panels reduce } \\
\text { costs of rooms conditioning. }\end{array}$ \\
\hline 3 & USA & New York & $\begin{array}{c}\text { Bank of } \\
\text { America } \\
\text { Tower }\end{array}$ & $\begin{array}{l}\text { The Bank is equipped with a system for } \\
\text { electricity generation running on natural gas. } \\
\text { It also has a system for collecting rainwater. } \\
\text { The building has large windows. They let a } \\
\text { lot of light. The sensors regulate the light } \\
\text { level in the room. }\end{array}$ \\
\hline 4 & USA & Chicago & $\begin{array}{l}\text { "340 on the } \\
\text { Park" }\end{array}$ & $\begin{array}{l}\text { There is an own collection system for } \\
\text { rainwater. It is used for technical purposes. }\end{array}$ \\
\hline 5 & USA & Manchester & The CIS Tower & $\begin{array}{l}\text { More than seven thousand panels mounted on } \\
\text { the walls of the building. } 24 \text { powerful wind } \\
\text { turbine installed on the roof of the tower. It } \\
\text { provides about } 10 \text { percent of the consumption } \\
\text { of energy for the building. }\end{array}$ \\
\hline
\end{tabular}

There consider the tallest hotels in the world. They are shown in Figure 4.

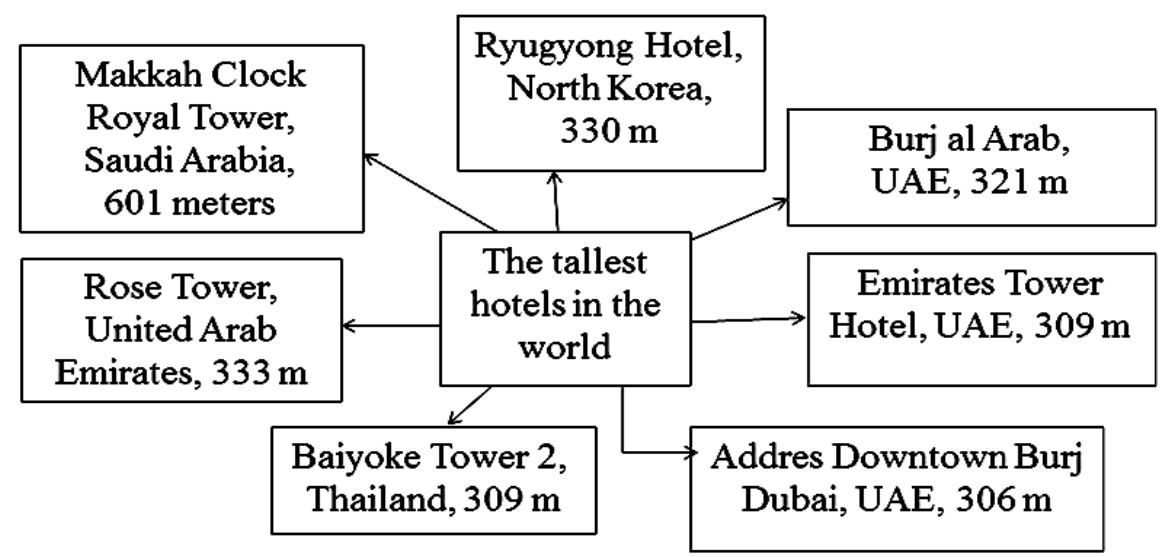

Fig. 4. The tallest hotels in the world.

\section{Results}

There consider some successful examples of creating high-rise buildings. These are Burj Khalifa in United Arab Emirates, Dubai; Tokyo Sky Tree in Japan; the Willis tower in Chicago and Federation Tower in Russia[6, 7] . 
Table 4 Successful examples of creating high-rise buildings

\begin{tabular}{|c|c|c|c|c|}
\hline $\mathrm{N}$ & Country & $\begin{array}{l}\text { The name of } \\
\text { high-rise } \\
\text { buildings }\end{array}$ & Purpose & Benefits \\
\hline 1 & $\begin{array}{l}\text { UAE, } \\
\text { Dubai }\end{array}$ & Burj Khalifa & $\begin{array}{l}\text { There attract } \\
\text { tourists }\end{array}$ & $\begin{array}{l}\text { It is the tallest building in the world } \\
\text { There is not heat up practically } \\
\text { There is the highest observation deck } \\
\text { There is the increase in property value } \\
\text { There attract tourists }\end{array}$ \\
\hline 2 & Japan & $\begin{array}{l}\text { Tokyo Sky } \\
\text { Tree }\end{array}$ & $\begin{array}{c}\text { There create the } \\
\text { most } \\
\text { earthquake- } \\
\text { resistant } \\
\text { building } \\
\text { There support } \\
\text { antennas } \\
\end{array}$ & $\begin{array}{l}\text { There can withstand earthquakes } \\
\text { There is the originality of design solution }\end{array}$ \\
\hline 3 & USA & Willis tower & $\begin{array}{l}\text { There located } \\
\text { offices and } \\
\text { business centers }\end{array}$ & $\begin{array}{c}\text { There attract tourists } \\
\text { There are heavy duty antennas. } \\
\text { There take over lightning strikes }\end{array}$ \\
\hline 4 & Russia & $\begin{array}{l}\text { Federation } \\
\text { Tower }\end{array}$ & $\begin{array}{l}\text { There located } \\
\text { elite apartments } \\
\text { (residential) and } \\
\text { modern offices }\end{array}$ & $\begin{array}{l}\text { There are high speed elevators. } \\
\text { There is automated system of ventilation } \\
\text { and conditioning. } \\
\text { There are energy efficient windows etc } \\
\text { It is one of the highest buildings in } \\
\text { Europe. } \\
\text { There are } 67 \text { elevators } \\
\text { There is speed super-modern escalators } \\
\text { and elevators } \\
\text { It was recognized the best office building } \\
\text { in the world in } 2009\end{array}$ \\
\hline
\end{tabular}

1. Let us consider more detailed the called skyscrapers:

1) The first is "Burj Khalifa". This is the tallest skyscraper in the world. The project of "Burj Khalifa" was designed by American architects. American architectural Bureau Skidmore, Owings and Merrill participated in the construction of "Burj Khalifa". American architect Adrian Smith was the author of the project. The building is a work of art and marvel of engineering. "Burj Khalifa" has no equal in the world. Different states took part in design and construction of the building. Burj Khalifa was inaugurated in Downtown Dubai on 4 January 2010. Since that time it has officially became the tallest building in the world. Skyscraper has a height of 828 meters and 163 floors. This is like a miniature "city within a city". Offices and hotels, retail and residential space and own parks and boulevards are located inside the skyscraper. The first 37 floors are given to the hotel. Residential premises are located from 45 to 108 floors, and other premises are mostly offices. There are two observation decks in the skyscraper:

1. The first observation deck locates on the 125th floor, at a height of 456 meters above the ground. This gives people opportunity to see amazing panoramic views of the surroundings.

2. The second observation deck locates on the 148th floor at a height of 555 meters above the ground,. This is the highest observation deck in the world under the open sky.

Burj Khalifa is not only tourist attraction in Dubai. The skyscraper has tower with a spire, equipped with communication equipment for working of networks of cellular communication. This skyscraper is not just the tallest building in the world. Today the Burj Khalifa is called differently.

-This is the highest skyscraper 
-This is the most multi-storey building

-This is the highest outdoor observation deck

- This is the high-rise building with the tallest lift

-This is the skyscraper with the high-speed elevator etc.

As a result, thanks to the skyscraper, this area and nearby areas became very prestigious, and therefore expensive. Statistics shows that the cost of such exclusive housing and commercial real estate grows, on average, by 35 percent. Moreover, it is not so important what about are in question. The cost of property near the skyscraper will be much higher than structures located away from it. Analysts believe that the rapid growth industries of tourism and trade occur in Downtown Dubai thanks to the presence of this skyscraper. In 2015 company AttractionTix declared that Burj Khalifa was the best attraction in the world. It helps to attract in Emirate of tourists from all over the world since its opening in 2010.

2. The second is "Tokyo Sky Tree" in Japan. In recent years many tall buildings have appeared. It worsened telecommunications. There were interruptions in communications. The signals were received from the old tower and they were poorly heard by last floors because of skyscrapers. Tokyo Sky Tree was built to solve this problem. In addition, the government planned to translate the country broadcasting in digital format. These and other moments have led to the need of designing the new tower. There was created the group of about 100 experienced professionals. Task was to do, not just television tower, but that it also was supposed to be earthquake resistant. "Tokyo Sky Tree" appeared in the capital by February 2012. There has emerged the world's second tallest building (634 meters) in Japan thanks to the creation of the tower. The opening of the tower was on May 22. There were involved 580 thousand people in construction. There was spent 812 million dollars. Built TV tower turned out to aseismic. Anti-seismic systems can withstand an earthquake of 7-ball force. The construction of Tokyo Sky Tree was made possible thanks to technical progress. Its height is 634 meters. This was built in 2011 and it was opened for visits of tourists in May 2012. The TV tower was built in just six years: the project was published in 2006 and it enacted in 2012. The authors of the skyscraper drew attention to three points at erection of Tokyo Sky Tree. These are the following points:

- The mixture of the traditional Japanese design with the newest modern technology.

- Tokyo Sky Tree contributed to increase capital at the expense of such grand construction

- The building was built by last word of safety regulations.

The tower must fulfill its production function. In this regard to it, its height had to exceed all existing buildings and those that might build later. The designers used new amortization technologies to protect the tower from earthquakes and hurricanes. The main goal is to support of the antennas. In addition to it, tourist use of this building was beforehand thought. Here everyone will find something to surprise oneself:

a) The tower was built in a not affluent area. Here there are many traditional Japanese buildings. So the view from the top is beautiful and varied. Tokyo Sky Tree has very high viewing platform.

b) Some people are interested in technology. They want to see unusual design solutions. They are also interested by the complexity of implementation of the anti-seismic protection.

c) Other people like exotic. They look from the height of the observation deck on buildings, which are made in traditional Japanese architecture.

3. The third example is "Willis Tower" in Chicago in USA. Each country has its own characteristics, its own symbols. Such symbol is the Willis Tower for USA. There was decided to profitably use 5000 square meters of land and to build a skyscraper in Chicago. In 1973, the tower was built. The building was erected quickly due to a number of circumstances:

1. A large number of workers worked to construct the building. These were about two and a half thousand people; 
2. There were uninterrupted financing. The cost of the building is estimated at $\$ 150$ million.

3. There were features of the design. Bruce Graham was chief architect of the building. Fazlur Khan was chief engineer. They took steel as the supporting material. Thanks to this choice, this design is able to withstand the strong blows of the Chicago winds.

The skyscraper has the height of 443 meters and 110 floors. During 25 years, the skyscraper was considered by the highest not only in USA. The tower was the highest in the world. Today the skyscraper is one of the tallest skyscrapers in the world. The inhabitants of Chicago are proud to say that they have the tallest building in the USA in their city. And they have a reason for pride:

1. Tourists come to see necessarily the observation deck. The observation deck locates on the 103th floor of the skyscraper. Every year, half a million people visit the skyscraper. During the day, 25 thousand people come here.

2. One can see $80 \mathrm{~km}$ around the observation deck if the weather is good.

3. The main purpose of the skyscraper is to place offices and business centers.

The skyscraper needed for broadcasting Chicago. Four heavy-duty antennas set on the roof of the building. They provide the signals this large city.

5. The above antennas avert lightning strikes approximately twice a day.

6 . The fans of extreme sports and climbers are interested in the skyscraper. This building can be used as a site for films and TV programs.

4. The fourth is "Federation Tower" in Moscow in Russia. Its height is 95 floors. This skyscraper is one of the projects of Mirax Group. All decisions were thought out in advance at its construction. Much attention was paid to quality, therefore the most modern technological innovations were used. The skyscraper is located in "Moscow City". Nowadays, this building is considered one of the tallest skyscrapers in Europe. "Moscow City" has two high-rise buildings: "East" and "West". They are united by a common six-story corridor. The complex has both elite housing and modern offices.

"Federation Tower" is about 10000 square meters, and the project is 443000 square meters. "West" has 243 meters and 95 floors. "The East" has a height of 374 metres. The skyscraper has 67 elevators. Architect Sergei Cioban and his German colleague Peter Schweger designed the project. Thornton Tomasetti is the designer of the project. Renaissance Construction is a contractor. The facade of the tower is glazed by Yuanda. Other foreign companies also participated in the construction of the skyscraper. This is an example of international relations, international cooperation. The bookmark of the tower "West" occurred in 2006. The construction of the tower was ended in 2008. The construction of tower "the East" began in 2007. Many organizations are located in Federation Tower. Many offices of premium-class exist for entrepreneurs. There are high-speed modern elevators and escalators in the building. Offices and a shopping gallery are located in the building. Business offices are mostly located in the skyscraper. They are in the western tower from 1 to 46 floors and they are in the east on 1-60 and 63-68 floors. The total area of offices is 287 thousand square meters. Luxurious residential apartments are located on the upper floors of the skyscraper. Platinum apartments are from 90 to 95 floors in the building "East" $[8,9,10]$.

\section{Discussion}

Different scientists have different attitudes to high-rise construction. Many recognize that this is necessary measure; some believe that it is one of the ways to exalt oneself. There exist the main reasons for the construction of high-rise buildings. The population is becoming more, and place for the erection of buildings is less. This is especially actually in large cities. The authors adhere to the two points of view about high-rise construction in Russian and foreign articles. Some people perceive high-rise construction as a benefit. Other authors refer 
to tall buildings warily or negatively. As an example, it is possible to consider article "Peculiarities of high-rise construction of the Central district of Yekaterinburg" by Shvets A. V. and Tarasova I. V. From our point of view in the article we can see that high-rise construction has both positive and negative sides. On the one hand, it "promotes the development of economy, business, tourism" and it is "at the forefront in the construction industry". On the other hand there are some features, which "determine negative attitude towards high-rise construction in both the public and the architectural community". For example, it may "violate historical and cultural heritage of the city" [11,12] From the point of view of the author of this article, opinions of various authors regarding the role of highrise construction can be very roughly divided as follows.

Table 5 The attitude of various authors [13]

\begin{tabular}{|c|c|c|c|c|}
\hline Author & The title of article & $+*$ & $-*$ & $+/$ +* $^{*}$ \\
\hline $\begin{array}{c}\text { Shvets A. V., Tarasova I. } \\
\text { V }\end{array}$ & $\begin{array}{l}\text { Peculiarities of high-rise construction of } \\
\text { the Central district of Yekaterinburg }\end{array}$ & & & $+/-$ \\
\hline $\begin{array}{c}\text { Kai Chen Goh, Hui } \\
\text { Hwang Goh, Mohd Faizal } \\
\text { Omar, Tien Choon Toh } \\
\text { and Abdullah Asuhaimi } \\
\text { Mohd Zin }\end{array}$ & $\begin{array}{l}\text { Accidents Preventive Practice for High- } \\
\text { Rise Construction }\end{array}$ & & - & $(+/-)$ \\
\hline O. Matejko & $\begin{array}{l}\text { The history of development and modern } \\
\text { trends in high-rise construction }\end{array}$ & + & & \\
\hline A.A. Aldeberky. & $\begin{array}{l}\text { The influence of high-rise buildings on } \\
\text { the environment }\end{array}$ & & - & \\
\hline Farzad Navaei. & $\begin{array}{l}\text { An Overview of Sustainable Design } \\
\text { Factors in High-Rise Buildings }\end{array}$ & + & & \\
\hline $\begin{array}{l}\text { Vinay Chandwani, Dr. } \\
\text { Vinay Agrawal, Naveen } \\
\text { Kumar Gupta }\end{array}$ & $\begin{array}{c}\text { Role of Conceptual Design in High Rise } \\
\text { Buildings }\end{array}$ & + & & \\
\hline $\begin{array}{c}\text { M. D. Kashin, T. B. } \\
\text { Nabokova, V. N. Bgashev }\end{array}$ & $\begin{array}{l}\text { Environmental interaction of high-rise } \\
\text { buildings and the environment - the } \\
\text { experience of foreign countries }\end{array}$ & & - & \\
\hline
\end{tabular}

Positive (+)* Negative (-)* In Two Ways (+/-)*

Let us consider the advantages and disadvantages of high-rise construction based on the opinion of various authors.

Table 6 The advantages and disadvantages of high-rise construction.

\begin{tabular}{|c|c|}
\hline Advantages & Disadvantages \\
\hline $\begin{array}{l}\text { - There plays a significant role in technical } \\
\text { progress, } \\
\text { - There promotes the development of business } \\
\text { - There promotes the development of tourism. } \\
\text { - There are addressed issues related to urban } \\
\text { transport } \\
\text { - There is a large number of private and public } \\
\text { investments } \\
\text { - There use labor resources actively etc. }\end{array}$ & $\begin{array}{l}\text { - There may be the violation of the } \\
\text { historic part of the city. } \\
\text { - There are deaths and accidents } \\
\text { - There are serious injuries } \\
\text { - There may be air pollution, } \\
\text { - People may feel uncomfortable on } \\
\text { the street and in a building } \\
\text { - There is strong wind etc. }\end{array}$ \\
\hline
\end{tabular}

In conclusion to the above table it can be noted that despite the fact that high-rise buildings are building more often, high-rise construction is still a high-risk area. 


\section{Conclusions}

Thus, we see both positive and negative sides of high-rise construction. Along with the positive impact tall buildings can have serious negative effects. On the one hand high-rise construction is increased risk and great responsibility, and, on the other hand, this is an indicator of prestige and high professionalism of its participants. Much depends on the literacy development of the project and the organization implementing it. In Russia high-rise construction will be carried out due to lack of available of land for building in major cities such as Moscow, St. Petersburg and others. This can be assessed in different ways. However, as for most cities in the world, it is a forced measure on the one hand, and, on the other, a tribute to fashion and prestige.

\section{References}

1. S. Gorin, Unique and express technologies in construction [Digital resource] Access mode: http://www.stroinauka.ru/detailview.asp (2004)

2. W. Leontief, The Structure of the American Economy, 1919-1929 (Cambridge: Harvard University Press, (1941) https://doi.org/10.1017/S0022050700053158 Published online: 01 February 2011

3. A. Terranova, Skyscrapers (New York: White Star Publishers, 2003)

4. M. Dhammy, High rise housing. Residential Towers [Digital resource] Access mode: https://ru.scribd.com/document/205050629/High-rise-housing

5. I. Rozhentsova et al, MATEC Web of Conferences $\mathbf{1 0 6} 08076$, DOI: https://doi.org/10.1051/matecconf/201710608076 (2017)

6. N. Braila, C. Vahrusheva, E. Martynenko, T. Kisel, IOP: Earth and Environmental Science, 90, 12030 (2017)

7. E. Vasilyeva, IOP (Earth and Environmental Science), 90, 12216 (2017)

8. E. Chibisova, A. Zinatullin, Strategy of sustainable development of regions of Russia 5 324-328 (2011)

9. I. Polyakova, E. Vasilyeva, IOP: Earth and Environmental Science 90012136 (2017)

10. E. Stein, N. Taskaeva, E. Chibisova, Procedia Engineering 165 1410-1416 (2016)

11. A. Mottaeva, MATEC Web of Conferences 7307020 (2016)

12. A. Mottaeva, IOP Conf. Series: Earth and Environmental Science 90012120 doi $: 10.1088 / 1755-1315 / 90 / 1 / 0121209$ (2017)

13. E. Petukhova ARX. The universal language of architecture 2 108-113 (2006) 